\title{
Kesulitan Belajar pada Anak Sekolah dengan Riwayat Berat Lahir Sangat Rendah
}

\author{
Adillida, SM Manoeroeng, Iskandar Z. Lubis
}

\begin{abstract}
Angka kehidupan bayi berat lahir sangat rendah semakin meningkat. Bagaimana perkembangan bayi berat lahir sangat rendah ini di dkemudian hari masih menjadi pertanyaan. Sebagian laporan mendapatkan bahwa terdapat berbagai gangguan perkembangan berupa kesulitan belajar dan gangguan tingkah laku pada anak-anak tersebut. Diperlukan suatu intervensi dan strategi penanganan untuk meningkatkan kualitas hidup anak tersebut di kemudian hari.
\end{abstract}

Kata kunci : kesulitan belajar, anak sekolah, berat lahir sangat rendah.

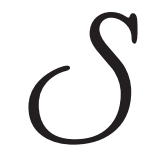

elama 20 tahun terakhir ini angka kehidupan bayi berat lahir sangat rendah (BBLSR) meningkat sejalan dengan meningkatnya pelayanan intensif neonatal dan perinatal. ${ }^{1}$ Angka kehidupan anak dengan berat lahir amat sangat rendah (500-1000 gram), di Amerika Serikat berkisar $63-79 \%,{ }^{2}$ namun bagaimana kualitas hidup mereka selanjutnya masih menjadi pertanyaan. ${ }^{2,3}$

Di lain pihak, angka kehidupan BBLSR telah meningkat namun proporsi anak BBLSR yang hidup dengan keadaan kecacatan berat berkisar antara $10-20 \%{ }^{1}$ Kecacatan tersebut terutama dalam hal defisiensi mental berat, serebral palsi, kebutaan dan ketulian berat. ${ }^{4}$ Gejala sisa BBLSR menjadi masalah sepanjang hidup anak, karena merupakan penyebab utama gangguan perkembangan saraf; rentan terhadap masalah kesehatan berupa penyakit infeksi sehingga membutuhkan perawatan rumah sakit yang berulang, dengan akibat pertumbuhan fisik terhambat. Kelainan tingkah laku dan attention disorder di kemudian hari banyak dilaporkan, sehingga anak memiliki kesulitan belajar pada masa usia sekolah dan membutuhkan bantuan pendidikan tambahan. ${ }^{5}$

Dr. Adillida, PPDS Ilmu Kesehatan Anak FK USU, Medan.

\footnotetext{
Alamat korespondensi:

Dr. Iskandar Z Lubis, Sp.A(K).

Bagian Ilmu Kesehatan Anak FK USU/RS H Adam Malik Jalan Bunga

Lau No. 17, Medan.

Telepon: (061) 8361721, Fax.: (061) 8361721.
}

Akhir-akhir ini BBLSR semakin mendapat perhatian khusus karena dampak kesulitan belajar di sekolah yang relatif lebih tinggi walaupun tanpa kecacatan yang berat. ${ }^{1}$ Sangat sedikit penelitian dan publikasi mengenai perkembangan anak BBLSR pada usia sekolah karena selain sulit dilakukan, memerlukan pemantauan jangka panjang sehingga dibutuhkan biaya tinggi. ${ }^{6}$

\section{Definisi}

Bayi berat lahir sangat rendah adalah bayi yang dilahirkan dengan berat badan kurang dari 1500 gram. ${ }^{7-9}$

Kesulitan Belajar (school difficulty): Anak dianggap memiliki kesulitan belajar apabila mereka harus mengulang kelas atau membutuhkan pendidikan khusus. ${ }^{5}$ McCormick dkk ${ }^{1}$ berpendapat bahwa anak dianggap memiliki kesulitan belajar apabila jawabannya ya (untuk salah satu atau keduanya) dalam pertanyaan berikut.

1. Untuk anak berusia 5-17 tahun yang mengikuti pelajaran khusus. Pertanyan: "Apakah anak mengikuti pelajaran khusus atau membutuhkan bantuan khusus di sekolah karena ketidakmampuan menerima pelajaran atau disebabkan adanya masalah kesehatan?"

2. pertanyaan kedua: "Apakah anak tersebut pernah mengulang kelas karena alasan apapun?.” 


\section{Manifestasi Kesulitan Belajar}

Diperkirakan 37\% anak BBLSR pada usia sekolah berisiko memiliki kesulitan belajar dan kelainan tingkah laku akibat adanya suatu neuro developmental delay. ${ }^{10}$ Kesulitan belajar di sekolah bermanifestasi sebagai berikut,

- Gangguan fungsi visual motor

Klein $\mathrm{dkk}^{10}$ dan Vohr $\mathrm{dkk}^{11}$ melaporkan bahwa anak-anak BBLSR memiliki fungsi visual motor yang lebih rendah dibandingkan dengan teman sekelasnya yang lahir cukup bulan.

- Gangguan persepsi Dijumpai sebanyak 33\% BBLSR dengan gangguan persepsi / perceptual - motor difficulties..$^{10}$

- Kesulitan membaca dan mengeja Dijumpai 66\% anak-anak BBLSR mengalami kesulitan membaca. Kesulitan membaca ini di jumpai pada kelompok anak dengan riwayat masa neonatus memiliki deviasi pada tonus, postur, gerakan, refleks atau lingkar kepala, dan $80 \%$ pada kelompok anak serebral palsi. ${ }^{11}$

- Kesulitan berhitung

Hunt $\mathrm{dkk}^{4}$ dan Saigal $\mathrm{dkk}^{5}$ mendapatkan bahwa anak-anak BBLSR mengalami kesulitan berhitung. Kesulitan berhitung merupakan tanda yang cukup sensitif untuk menilai adanya gangguan kesulitan belajar.

- Bahasa

Hunt $\mathrm{dkk}^{4}$ dan Marlow dkk ${ }^{12}$ melaporkan tingkat kemampuan membaca anak-anak BBLSR lebih rendah dari pada lahir normal. Halsey $\mathrm{dkk}^{2}$ melaporkan bahwa masalah bahasa merupakan faktor yang paling menonjol, $75 \%$ dari anak BBLSR memerlukan terapi bicara, latihan membaca, atau bantuan belajar.

- Gangguan tingkah laku

Beberapa peneliti mendapatkan bahwa anak BBLSR sering disertai dengan tingkah laku yang tidak sesuai di kelas. Hal ini dihubungkan dengan adanya masalah emosional (kecemasan, ketakutan, tidak bahagia, tics, dan cerewet) serta aktifitas berlebihan (gelisah, resah, dan tidak ada perhatian). McCormick $\mathrm{dkk}^{1}$ melaporkan dari beberapa problem tingkah laku anak yang dinilai dengan the behavior problem index ditemukan sikap anti sosial, depresi / ansietas, keras kepala, hiperaktif, immature, dan konflik dengan temannya, sedangkan sikap hiperaktif anak tampak mencolok

\section{Faktor-faktor yang Berhubungan dengan Kesulitan Belajar}

Beberapa faktor yang erat hubungannya dengan timbulnya kesulitan belajar pada anak BBLSR saat usia sekolah adalah,

- Faktor perinatal

Faktor-faktor risiko terhadap perkembangan kognitif pada anak BBLSR periode perinatal adalah perdarahan intrakranial dan problem pernafasan. Defisit kognitif dijumpai sekitar 7$21 \%$ dari kelompok risiko perinatal. ${ }^{13}$

- Lingkar kepala

Menurut Hack $\mathrm{dkk}^{14}$, anak BBLSR walaupun tidak menderita kelainan neurologis, lingkar kepala yang subnormal (kurang dari mean -2 SD) pada usia sekolah merupakan faktor prediktif terhadap adanya gangguan bahasa, membaca, matematika, dan kejadian hiperaktif yang tinggi.

- Usia anak

McCormick dkk ${ }^{1}$ melaporkan bahwa kesulitan belajar lebih banyak ditemukan pada kelompok usia 12-17 tahun dibandingkan dengan kelompok usia 4-11 tahun; sedangkan Saigal $\mathrm{dkk}^{5}$ melaporkan adanya kognitif yang lebih rendah dengan makin bertambahnya usia.

- Jenis kelamin

Anak laki-laki BBLSR lebih sering mengalami kesulitan belajar dibandingkan anak perempuan. ${ }^{1}$

- Pendidikan orang tua

Pendidikan ibu yang rendah merupakan faktor kuat yang berpengaruh terhadap kesulitan belajar pada anak BBLSR. ${ }^{1,5}$ Hunt $\mathrm{dkk}^{4}$ menemukan interaksi antara pendidikan orang tua dengan kesulitan belajar pada anak.

- Status sosial ekonomi

McCormick dkk ${ }^{1}$ dan Vohr $\mathrm{dkk}^{11}$ melaporkan anak dengan status sosial ekonomi keluarga yang rendah lebih sering membutuhkan pendidikan khusus dari pada status sosial ekonomi yang cukup.

- Usia kehamilan

Hack dkk ${ }^{15}$ melaporkan bahwa anak BBLSR kecil masa kehamilan (KMK) akan memiliki perkembangan dan intelektual yang lebih rendah dibanding dengan BBLSR sesuai masa kehamilan (SMK), namun Marlow $\mathrm{dkk}^{12}$ tidak menemukan perbedaan pada kedua kelompok tersebut.

- Faktor lain

Menurut McCormick $\mathrm{dkk}^{1}$, faktor lain yang 
erat hubungannya dengan kesulitan belajar pada anak BBLSR adalah usia ibu yang masih remaja saat melahirkan, anak dengan jumlah saudara yang lebih banyak, serta anak dengan orang tua yang memiliki status kesehatan yang kurang baik.

\section{Pilihan Intervensi dan Strategi Penanganan}

Program intervensi dini pada anak BBLSR telah memperlihatkan manfaat terhadap kesehatan dan perkembangan anak-anak tersebut pada masa usia pra sekolah. Para ahli banyak yang mendukung perlunya intervensi dini dilakukan pada masa rawat di unit perawatan intensif neonatus, sebelum bayi tersebut dipulangkan ke rumah, bukan dari program yang bersifat home base atau center-based program. ${ }^{16}$ Namun Ramey $\mathrm{dkk}^{17}$ berpendapat bahwa untuk meningkatkan perkembangan yang sesuai, pada BBLSR dibutuhkan selain interaksi sosial oleh orang tua juga dibantu dengan pengetahuan dan pendidikan yang profesional.

Intervensi yang dapat dilakukan meliputi,

1. Intervensi dini

Suatu stimulasi suplemen (suplementalstimulation) dimulai segera setelah lahir dan dilanjutkan sampai berat badan mencapai berat badan bayi cukup bulan (aterm) dan pulang dari rumah sakit. ${ }^{18}$ Field $^{18}$ dan Roesli ${ }^{19}$ berpendapat bahwa setelah lahir, neonatus BBLSR merasa lingkungan baru kurang nyaman, terang benderang, ribut, merasa seorang diri, sehingga diperlukan stimulasi yang disesuaikan.

Beberapa modalitas stimulasi terdiri dari,

- Auditory stimulating; dengan mendengarkan suara / denyut jantung ibu melalui inkubator saat bayi tidur.

- Non-nutritive sucking stimulation ; memiliki pengaruh positif terhadap percepatan maturasi refleks menghisap, mempercepat transisi pemberian oral feeding, mengurangi transit time intestinal sehingga mempercepat kenaikan berat badan.

- Tactile / kinesthetic stimulation atau dikenal dengan pijat bayi, merupakan stimulasi terbaik terhadap perkembangan dan pertumbuhan bayi. ${ }^{19}$

- Visual stimulation.

- Social stimulation.
Program stimulasi multi model ini perlu berlangsung berminggu-minggu bahkan berbulan-bulan.

2. Kunjungan rumah (home base) $)^{17,20,21}$

Dilakukan setiap minggu pada tahun pertama dan setiap dua minggu setelah 36 bulan dengan protokol/kurikulum sebagai berikut,

- Program pengembangan kognitif, linguistik, dan sosial dengan memakai permainan dalam aktifitas stimulasi oleh orang tua terhadap anaknya.

- Pendekatan dilakukan secara sistematis untuk membantu orang tua menangani masalahmasalahnya sendiri.

3. Pusat perkembangan anak (center-based program $)^{20,21}$ Pelatihan di paruh perkembangan awal dimulai sejak anak usia 12 bulan dan dilanjutkan sampai usia 3 tahun, anak hadir 5 hari per minggu. Pelatihan ini merupakan lanjutan aktifitas belajar di rumah dengan program yang disesuaikan untuk kebutuhan anak dan tingkat perkembangan. Guru/pengasuh yang bertugas di pusat perkembangan harus mengerti kebutuhan anak.

4. Kelompok orang tua ${ }^{20,21}$

Dimulai saat usia anak mereka 12 bulan di adakan pertemuan kelompok orang tua setiap dua bulan untuk membahas kesehatan dan perkembangan anak.

Intervensi yang telah diterangkan, pertama kali dikembangkan oleh Universitas Stanford California dengan nama the infant health and development program dengan harapan akan mampu meningkatkan nilai akademis yang lebih tinggi pada anak BBLSR, mengurangi remedial class, dan menurunkan risiko tinggal kelas, putus sekolah, selanjutnya mungkin akan mengurangi juvenile delinquency, dan meningkatkan status kerja. ${ }^{21}$

\section{Kesimpulan}

Anak dengan berat lahir sangat rendah pada usia sekolah dapat memiliki kesulitan belajar dan gangguan tingkah laku. Intervensi dini berupa suplementasi stimulasi segera setelah lahir dan stimulasi belajar pada perkembangan selanjutnya, diharapkan akan meningkatkan kualitas anak dengan berat lahir sangat rendah di kemudian hari. 


\section{Daftar Pustaka}

1. McCormick MC, Gortmaker SL, Sobol AM. Very low birth weight children: behavior problems and school difficulty in a national sample. J Pediatr 1990; 117:687-93.

2. Halsey CL, Collin MF, Anderson CL. Extremely lowbirth weight children and their pears. Arch Pediatr Adolesc Med. 1996;150:790-4.

3. Kitchen W, Ford G. Orgill A. Outcome in infant of birth weight 500 to $999 \mathrm{~g}$ : a continuing regional study of 5year old survivors. J Pediatr 1987; 111:761- 6.

4. Hunt JV, Cooper BA, Tooley WH. Very low birth weight infants at 8 and 11 years of age: role of neonatal illness and family status. Pediatrics 1988; 82:596-603.

5. Saigal S, Hoult LA, Streiner DL. School difficulties at adolescence in a regional cohort of children who were extremely low birth weight. Pediatrics 2000; 105:32531 .

6. Saigal S, Szatmari P, Rosenbaum P. Intellectual and functional status at school entry of children who weighed 1000 grams or less at birth: a regional perspective of birth in the 1980s. J Pediatr 1990; 116:409-16.

7. Markum AH. Janin dan neonatus. Dalam: Markum AH, Penyunting. Buku ajar ilmu kesehatan anak. Edisi ke-2. Jakarta: Balai Penerbit FK UI 1991. h. 224-5.

8. Kliegman RM. The fetus and the neonatal infant. Dalam: Behrman RE, Kliegman RM, Arvin AM, Penyunting. Nelson textbook of pediatrics. Edisi ke-15. Philadelphia: Saunders 1996. h. 454-5.

9. Ogata ES. The small for gestational age neonate. Dalam: Cowett MR, Ed. Principles of perinatal neonatal metabolism. Edisi ke-2. Springer. h. 1097-103.

10. Klein N, Hack M, Gallagher J. Preschool performance of children with normal intelligence who were very low birth weight infants. Pediatrics 1983; 75:531-7.

11. Vohr BR, Coll CTG. Neurodevelopmental and school performance of very low birth weight infants: a seven year longitudinal study. Pediatrics 1985; 76:345-50.

12. Marlow N, Roberts L, Cooke R. Outcome at 8 years for children with birth weights of $1250 \mathrm{~g}$ or less. Arch Dis Child 1993; 68:286-90.

13. Leonard CH, Clyman RI, Piecuch RE. Effect of medical and social risk factors on outcome of prematurity and very low birth weight. J Pediatr 1990; 116:620-6.

14. Hack M, Breslau N, Waissman B. Effect of very low birth weight and subnormal head size on cognitive abilities at school age. N Engl J Med 1991; 325:231-7.

15. Hack M, Merkatz IR, McGrath SK. Catch-up growth in very low birth weight infants. AJDC 1984; 138:370-5.

16. Gunn BJ, Liaw F, Klebanov PK. Effects of early intervention on cognitive function of low birth weight preterm infants. Pediatr $1992 ; 120: 350-9$.

17. Ramey CT, Bryant DM, Wasik BH. Infant health and development program for low birth weight, premature infant : program elements, family participation, and child intelligence. Pediatrics 1992; 89:454-65.

18. Field TM. Intervention for premature infants. J Pediatr $1986: 183-91$.

19. Roesli U. Pijat bayi prematur. Disampaikan pada seminar ilmiah IDAI Cab. Sumatera Utara, Brastagi, 27 Agustus 2000.

20. Mc Cormick MC, Mc Carton C, Tonascia J. Early educational intervention for very low birth infants : results from the infant health and development program. J Pediatr 1993; 123:527-33.

21. The infant health and development program. Enhancing the outcomes of low birth weight, premature infants. JAMA 1990; 263:3035-42. 